\title{
Mapping India since 1767: transformation from colonial to postcolonial image
}

\begin{abstract}
Indian civilization has over 2500 years of mapping tradition. With the establishment of the Survey of India in 1767, British rulers initiated the mapping of colonial India with high precision and accuracy. They started mapping to establish British power and supremacy in the Indian subcontinent that portrayed a British image of India. Following independence in 1947, the Survey of India and other national agencies started mapping India for planning and development. Hence, questions have been raised that, how far British image of India have been transformed into an Indian image. In this context, in this paper an attempt has been made to analyse the mapping of India from the perspectives of transforming a colonial into a postcolonial image. The transformation occurred mainly in terms of purpose i.e. maps as a tool for the expansion of territory to planning, development and governance, from analogue to digital in method and in strategy from restricted to liberal access.
\end{abstract}

\section{Keywords}

Colonial India • Indian civilization • Indian subcontinent • Postcolonial • Survey of India

(C) University of Warsaw - Faculty of Geography and Regional Studies

\author{
Tarun Kumar Mondal \\ Department of Geography, University of Kalyani, India \\ e-mail: mondaltarunkly@gmail.com \\ Received: 3 December 2018 \\ Accepted: 20 May 2019
}

Introduction

Indian civilization has over 2500 years of mapping tradition. During ancient period, Indian scholars were familiar with the idea of scale, length, shape, area and angles. Archeological excavations of the magnificent cities of Indus Valley Civilization (Mackay 1938), hymns and chants of ancient Indian texts viz. Sulvasutras (Seidenberg 1978; van der Waerden 1983; Staal 1999) corroborate this claim. This legacy continued in the mathematical and astronomical works of great Indian scholars viz. Aryabhatta, Barahamihira, Bhāskara and Bhaskaracharya spanning the $5^{\text {th }}$ to the $12^{\text {th }}$ century (Amma 1979; Waerden 1983). However, this glorious tradition seemed to be paused due to political and economic instability in Indian subcontinent. During $16^{\text {th }}$ and $17^{\text {th }}$ centuries, maps were prepared and used by the Mughal rulers to run smooth administration and establish a generalized revenue collection (Habib 1974; Gole 1988). Since the $17^{\text {th }}$ century Europeans had also widely identified Indian Territory through maps for the expansion of trade and commerce (Gole 1976). Another significant native tradition of mapping was developed in India by the Maratha rulers during the $17^{\text {th }}$ and $18^{\text {th }}$ centuries (Gogate \& Arunachalam 2008). The history of Indian cartography entered into a new era in 1767 with establishment of the Survey of India (SOI) as the survey and mapping of India were taken over by the British colonial rulers.

British rulers initiated mapping their territories and beyond in India with great accuracy. They started mapping to establish British power and supremacy in Indian subcontinent. Consequently, maps prepared during colonial period portrayed a British image of India. However, unification of Indian Territory through maps paved the way for realization of Indian nationhood. After achieving independence in 1947, the Survey of India was entrusted with the responsibility of mapping India for nation building. Since then, for planning and development, maps of India in diverse categories have been generated. As all these maps in the postcolonial period were developed mainly according surveys by the British surveyors, questions have been raised regarding the extent to which the British image of India has been transformed into an Indian image. In search of the answer to this question, this paper attempts to analyse Indian mapping perspectives and its transformation from a colonial to a postcolonial image. The paper is divided into three main sections; the first section portrays mapping India during the colonial period and the establishment of British Image of India. The second section highlights the development of mapping India during the postcolonial period. Finally, the third section analyses, whether the British image of India has been transformed into an Indian image in terms of purpose, methods and strategy.

\section{Methodology}

This study has covered the evolution of map making from establishment of the Survey of India in 1767 to present day India. Archival materials, key maps and significant contributions of previous scholars in this field have been examined in this study.

Phillimore's monumental work on Historical Records of the Survey of India (1945-58, vols.1-5), Edney's (1997) Mapping an Empire: The Geographical Construction of British India, 17651843, Markham's (1878) A Memoir on the Indian Surveys, Keay's (2001) The Great Arc, The Dramatic Tale of how India was Mapped and Everest was Named and Barrow's (2004) Making History, Drawing Territory: British Mapping in India, c. 1756-1905 have been 
essentially considered to portray the colonial image of India. In addition to scholarly articles, relevant reports and documents on the progress of Indian mapping after its independence, published by the various national agencies viz. Survey of India, National Remote Sensing Centre, National Atlas and Thematic Mapping Organization and Indian Space Research Organisation have been used in this study. Hence, the paper involves a synthesis of existing research on the transforming image of India from the colonial to the postcolonial period.

\section{Mapping India during the Colonial Period}

The Survey of India was started by James Rennell, the first Surveyor General of Bengal (Phillimore 1945). His concerted effort to survey and map India laid the strong foundation of mapping during colonial period. A Bengal Atlas (1781) and Memoir of a map of Hindoostan; or, The Mogul empire (1788) were the legendary works of Rennell. Rennell's map of Hindoostan was first published in 1782 and the map was based on information mainly collected from "the early historical and geographical evidence available, and he had a wealth of additional material collected by the surveys of the last 25 years" (Phillimore 1945, p.4). Primarily this map was used by British rulers to imagine their future possession, as this map was the first comprehensive visual representation of the British image of India. However, this map was not free from criticism, particularly in terms of lack of accuracy, precision and information (Phillimore 1945).

The Great Trigonometrical Survey (GTS) in colonial India was one of the glorious mega projects for measuring the Indian subcontinent with high precision. The GTS of India was started by William Lambton on $10^{\text {th }}$ April, 1802 with the measurement of a baseline near Madras (now Chennai). Lambton selected a plain surface to measure the baseline of 7.5 miles in length bounded by St. Thomas' Mount to the north and Perumbauk hill to the south and finally completed this work on $22^{\text {nd }}$ May, 1802 (Markham 1878). The accuracy of the determination of the longitude of Madras was maintained with the highest precision possible at that time. This line was considered as the baseline for measurement of the Great Indian Arc of the Meridian, near the $78^{\circ} \mathrm{E}$ meridian, north-south direction (Keay 2001). With the efforts of Lambton, the Great Arc was subsequently extended up to 1600 miles in length across the Indian subcontinent and this has remained the reference location for determining locations in all other surveys (Keay 2001).

16 years after its initiation, the Great Trigonometrical Survey (GTS) was officially recognized on $1^{\text {st }}$ January, 1818, same year that Capt. George Everest joined this survey as Chief Assistant to Lambton (Phillimore 1954). However, by this time, Lambton had completed the incredible work of measuring the Great Arc extending from Cape Comorin to Berar as well as the "upwards of 165,000 square miles of triangulation in Southern India" (Strahan 1902, p. 143). Measurement of the Great Arc was attempted not only for measuring the subcontinent but also to determine the actual curvature of the globe (Keay 2001).

For another five years (1818-1823), this enigmatic duo William Lambton and George Everest continued surveying the subcontinent and after Lambton died in 1823, Everest was appointed Superintendent of the GTS of India (Heaney 1967). Everest carried forward the Great Arc of triangulation series "across the Narbada to Sironj". In 1830, Everest was appointed as the Surveyor General of India along with his previous responsibilities as Superintendent of the GTS of India (Heaney 1967). After resuming the Great Arc series in 1832, Everest completed the gigantic task of measuring the Great Meridional Arc by triangulation covering "over 1500 miles from Cape Comorin in the south to Dehra Dun at the foot of the Himalayas" (Arnold 2000, p.41). Based on GTS, Indian Geodetic datum was adopted by
Everest in 1830 and subsequently adjusted in 1888 and in 1956. Kalyanpur (Latitude $24^{\circ} 07^{\prime} 11.26^{\prime \prime} \mathrm{N}$; Longitude $77^{\circ} 39^{\prime} 17.57^{\prime \prime} \mathrm{E}$ ) is the Everest datum reference point (initial point of origin), located in Madhya Pradesh, India (Srivastava 2014).

After Everest, Andrew Waugh was appointed as the Surveyor General of India and Superintendent of the GTS of India, held the office to 1861 and carried the GTS forward (Markham 1878). The history of mapping India during this phase had another remarkable achievement; under the leadership of Waugh, the heights of 79 Himalayan peaks were measured (Roy 1986). The head GTS computer, Radhanath Sikder, measured the height of the highest peak of the world $(8848 \mathrm{~m}$ ) for the first time, which was later named as Mt. Everest (after the name of great surveyor Sir George Everest).

After retirement of Waugh in 1861, Offices of the Survey of India and GTS were separated; Colonel Walker joined as the Superintendent of the GTS and Colonel Thuillier as the Surveyor General of India (Roy 1986). Walker completed the longitudinal series of the GTS by 1866 (Mishra et al., 2015).Walker and Thuillier started survey of another most difficult terrain i.e. Jammu and Kashmir during the period 1855-65. In 1855, the triangulation of Kashmir was initiated by Thomas Montgomerie from Jammu and afterwards across Pir Panjal, Kashmir Valley to the Great Himalayan range, Nanga Parbat and Karakoram Range (Phillimore 1968). The height of $K_{2}$ was first measured by Montgomerie in 1856 (8611 $\mathrm{m}$, the second highest mountain peak in the world). Maps of Jammu and Kashmir (quarter inch) were completed in 1861 (Phillimore 1968).

Survey and mapping of the Himalaya and the regions to the north of it would have remained incomplete without the contribution of two Indian legends Pundit Nain Singh Rawat (1830-1882) and Pundit Kishan Singh Rawat (18501921). Pundit Nain Singh Rawat explored the regions in Nepal, Tibet and also course of Brahmaputra River and route survey was conducted in Tibet, Mongolia and Central Asia during 1865-1885. However, the missions to Sind, Kabul and Lahore were conducted by the British surveyors much earlier during 1808 and 1810 due to the fear of a invasion of India by Napoleon (Phillimore 1950). For the same reason, field survey was also conducted by the British surveyors on the frontiers of Gujarat during 1809-10 (Phillimore 1950).

In 1905, a new topographical survey was initiated by Survey of India to produce coloured and contoured maps on 1 inch to 1 mile scale along with a subsequent revision twenty five years later (Heaney 1952). However, this initiative was not accomplished due to financial crisis, shortage of man power and the advent of Second World War in 1939 (Heaney 1952). By this time, Survey of India had done commendable job creating numerous large and small scale maps with uniform cartographic principles and techniques. These maps were used for revenue collection, generation of land holding records, expansion of transport networks, mining and obviously for the expansion of the British colony and their defence. These maps inevitably assisted the British to make and implement laws. Barrow (2004) stated that colonial maps of India demonstrate the "history of possession". According to him "that history is displayed in many ways-as the rapid spread of the colour red across the map of British-controlled India, as the naming of a Himalayan mountain, as the disingenuous transformation of revenue land into British territory" (Barrow 2004, p. 1).

However, maps produced by the survey of India not only assisted the colonial rulers to portray their dominance over Indian territory in a consolidated manner, but also led the native Indians to imagine their mother land. The maps were instrumental in creating a sense of national identity and conceive the idea of Indian nation state among people of India. Eventually, at the end of the war, the demand for Indian independence was raised 
much strongly than ever before. As colonial rule came to an end in 1947, the boundary of India was delineated mainly on the basis of two significant borders i.e. the McMohan Line (between India and China) and the Radcliffe Line (between India and Pakistan). Thus the glorious history of mapping in colonial India ended after almost two hundred years. A new era began with the mapping of independent India, the Survey of India being the apex agency for surveying, mapping and delineating the boundaries of the country.

\section{Mapping India during the Postcolonial Period}

Following independence in 1947, Survey of India was entrusted with new responsibilities amidst the challenge of a huge influx of refugees, communal riots, severe food shortage, extreme poverty, hunger and continuous tension along the boundaries. The new maps were needed neither to explore a potential colony nor govern it, but to assist the policy makers and administrators to solve these emerging problems in India. Consequently, Survey of India started producing various types of maps i.e. topographical, geographical and several public series maps covering the whole India at different scales (Survey of India, Annual Report, 2016-2017). Since then all types "Scientific Surveys" i.e. "geodetic and geophysical surveys, seismicity and seismotectonics studies, environmental and disaster management, participation in Indian scientific expeditions to Antarctica, glaciology programmes and other projects related to digital cartography and digital photogrammetry" (Survey of India, Annual Report 2016-2017, p.1) have remained as the primary responsibility of Survey of India. Survey of India is also engaged in the demarcation of the boundaries of India with neighbouring countries and the depiction of this on map and as adviser to Government of India in the demarcation of inter-state boundaries (Survey of India, Annual Report 2016-2017).

The requirement for accurate and precise maps for planning and governance led to the establishment of the National Atlas Organization in 1954, which was renamed as the National Atlas and Thematic Mapping Organization (NATMO) in 1978. Based on analogue and digital data, various thematic maps especially detailing physiography, drainage, climate, hydrology, soil, vegetation, agriculture, industry, minerals, settlements, transport as well as political and social criteria were produced by NATMO. Atlases and planning maps at different scales e.g. city maps, district maps, state maps are also prepared by NATMO.

In 1974, another significant organization, the National Remote Sensing Agency (renamed as National Remote Sensing Centre in 2008) was established as India entered into space research, mainly aerial photography and satellite remote sensing. This is the nodal agency for the procurement and distribution of aerial photos and satellite images. Since the advent of indigenous satellite systems, mainly Indian Remote Sensing Satellites (IRS), mapping and cartography in India has significantly entered into digital mode. High resolution Satellite images along with existing analogue maps are now used for planning, research, defence and administration. The IRS series satellite images are also used by different countries for similar purposes. Since 2005, different series of Cartosat satellites have been launched by ISRO especially for cartography and mapping.

Continuing the legacy from its colonial rulers, India, therefore has maintained the tradition of high precision and accuracy in mapping during the postcolonial period. However, to uphold national security as well as to provide geo-spatial data and information for scientific research, maps produced by these agencies are now available in two different series i.e. the Defence Series and the Open Series. Under National Map Policy, 2005, Defence Series Maps (DSM) are prepared on Everest/WGS1984 datum, polyconic or UTM (Universal Transverse Marcator) projection with scales: $1: 250,000 ; 1: 50,000$ and 1:25,000 (Govt of India, National Map Policy 2005). These maps contain classified information and allowed to access by the civilians based on the guidelines framed by Ministry of Defence, Government of India (Govt. of India, National Map Policy 2005). Open Series Maps (OSM), on the other hand, are prepared on WGS 84 datum and UTM projection and are freely available for Indian citizens. As per National Map Policy, 2005, Survey of India will be the sole authority to prepare and publish OSMs for developmental activities in the country.

In this new era of digital cartography and mapping in India, several web portals and data sharing platforms are now available for easy access, networking and sharing geo-spatial data and information. The National Data Sharing Accessibility Policy (Govt. of India, NDSAP 2012) was formulated in 2012 to ensure the sharing of data on both analogue and digital platforms for developmental activities (Survey of India, Annual Report 2016-2017). The National Topographic Database was generated by Survey of India.

Three important spatial web services i) Bhuvan: Indian Geo Platform of ISRO, ii) India-WRIS: Water Resources Information System of India and iii) National Information System for Climate \& Environment Studies (NICES) are now available. Bhuvan was designed for the earth observation service, IWRIS for "Single Window Solution" to all water related data and NICES for climate and environmental impact related assessment. Beyond mapping and digital database generation, India has already ventured in the field of navigation. GAGAN - GPS Aided GEO Augmented Navigation an Indian Satellite Based Augmentation System and IRNSS- Indian Regional Navigation Satellite System Program are the two flagship programmes initiated by Indian Space Research Organization. GAGAN has been designed for aviation purpose and it is presumed that in future general surveys for rectification of cadastral maps will be carried out using of this system (GNSS News Letter, July 2015). On the other hand, IRNSS is an indigenously developed satellite based navigation system for the regions in and around India. With the development of all these new technologies, India shows her potential to be one of the global leaders in survey, mapping and geo-spatial database development.

Since 1947 Mapping India has been dedicated to nation building. Maps are continuously being used for defence, administration, demarcation of intra-state, inter-state and international boundaries, resource availability and use, analysis of socio-economic conditions of the people, regional pattern of demographic dynamics, urban planning and development. Moreover, Satellite images, Digital cartography and Web portals are being used to update data and information not only by the citizens of India, but also by the neighbouring countries. Maps are part of the curriculum in schools and colleges. Cartography and Mapping science are two significant areas of research in India.

\section{Transformation from Colonial to Postcolonial Image}

A review of the 250 years history of survey and mapping in India reveals distinct transformations from the colonial to the postcolonial image of India. In the colonial era, the British aggression and history of colonization of the Indian sub-continent is "mingled with the history of survey" (Roy 1986, p.24). Edney (1997, p. 32) stated that "by measuring the land, by imposing European science and rationality on the Indian landscape, the British distinguished themselves from the Indians". British surveying in India transformed "the mystical, religious, Hindu space of India into a rational, scientific, imperial space" (Edney 1997, p. 19). British mapping evidently portrayed "their India" instead of the "real India" (Edney 1997). The British maps of India during the eighteen and nineteenth centuries are, therefore, all about their control 
over India and also an expression of their national victory (Barrow 2004). In contrast, the postcolonial maps are Indian efforts to portray an image of a five thousand year old civilization and the country with the largest democracy in the world. In this course of transformation from colonial to postcolonial image of India, distinct changes have been observed in i) Purpose, ii) Method and iii) Strategy of map making.

In expanding British territory over Indian subcontinent and establishing their rule across the colony, Survey of India did one of the most difficult tasks. Survey of India accurately provided geographical information of unknown territories during the colonial period. After independence, with the demarcation of the National Boundary, exploring new territories became a redundant exercise. The purpose of surveying and mapping India is now to know the micro-details of Indian terrain. Maps are required for a) security and defence of the nation rather than aggression and accession, b) for better governance of the administrative units rather than dominating the natives and c) for planning and overall development of the country rather than exploration and exploitation of resources in the interest of the colonial rulers. Only in the postcolonial era do the maps of India portray it as a single political unit, an independent nation outside the British Empire.

Surveying and mapping in India underwent a sea change after the introduction of aerial photography and satellite images particularly after the launch of IRS Mission. The old topographical sheets are being updated with the help of these technologies. To ensure international compatibility and enable cross border mosaics of these images, UTM projection and WGS84 datum are now used by NRSC, SOI and NATMO.

During the colonial period, Indian maps prepared by the British were unknown to the vast majority of Indian people. Maps of India are now available for everyday use. Students from their early school days learn about their motherland "INDIA" studying these maps. Maps and other geo-spatial data produced by the national agencies are now easily accessible for scientific research, planning and development not only for Indian citizens but also in other countries. The strategy of restricting the use of maps has been replaced by liberal access in the civilian domain.

The geography of India has been shaped and reshaped by the rulers for more than 5000 years. However, the gigantic task of systematic surveying and mapping of the subcontinent was first attempted by the British and they truly established the British image of India. The GTS in colonial India remained the backbone of Indian Survey and Mapping. After Independence in 1947, the colonial image of India has been gradually transformed into the postcolonial image by the efforts of Indian mapping agencies.

\section{Conclusion}

Territoriality of nation state has always been imagined and portrayed through maps. Maps have unified the national image and nurtured national identity even though they remained instrumental in displaying power and dominance. The evolution of cartography is therefore inseparable from the history of the formation of states, either in the colonial or postcolonial era. Mapping India, a subcontinent earlier divided into hundreds of independent, princely states, intermingled with vast tracks of tropical forests, was first unified by the efforts of the British surveyors and cartographers under the aegis of Survey of India. British surveyors preceded the British Army in this unknown land, thus connecting Kashmir to Cape Comorin and Balochistan to Myanmar in a map. The mapping of British India unified this subcontinent into a single political unit. Moreover, it explicitly specified that the Indian subcontinent is part of the British Empire, ruled by the British. In spite of the argument regarding the extent to which native Indians had access to these maps so they could imagine the extent of their nationhood, it is assumed that Indian leadership was familiar with the maps as many of them were trained in British Institutions. Moreover, survey and map making team in British India was not devoid of native Indians, eventually spreading this art. It is therefore obvious that, emancipation of the motherland from the foreign rulers and the establishment of independent India were conceived through drawing boundaries between the territories of Britain and India. In 1947, as these boundaries were drawn, Indian Territory was clearly demarcated and gradually established; maps changed and so did nationhood.

Continuing with the long tradition of indigenous cartographic knowledge, the mapping of India entered into a new era ever since Survey of India was established. This legacy has been continuing however; British perspectives of mapping India have been transformed into Indian concepts in the context of independence. For the last seven decades, Indian agencies have transformed the colonial image of India to the image of an independent nationstate with maps with new techniques, symbols and design.

\section{References}

Amma, TAS 1979, Geometry in Ancient and Medieval India, Motilal Banarsidass Publishers Private Limited, Delhi.

Arnold, D 2000, The New Cambridge history of India, science, technology and medicine in Colonial India, Cambridge University Press, Cambridge.

Barrow, IJ 2004, Making history, drawing territory: British mapping in India, c. 1756-1905, Oxford University Press, New Delhi.

Edney, MH 1997, Mapping an empire: The geographical construction of British India, 1765-1843, University of Chicago Press, Chicago.

GNSS, 2015, News Letter, vol.1. Available from: <http://gagan. aai.aero/gagan/sites/default/files/GNSS $\% 20$ News $\% 20$ Letter\%20Volume\%20001\%20July\%202015.pdf>. August 2017].

Gogate, PP \& Arunachalam, B 1998, 'Area maps in Maratha cartography: A study in native maps of Western India', Imago Mundi: The International Journal for the History of Cartography, vol.50, no.1, pp.126-140.

Gole, S 1976, Early maps of India, Sanskriti in association with Arnold Heinemann, New Delhi.

Gole, S 1988, Maps of Mughal India, Manohar, New Delhi.
Govt. of India 2005, National Map Policy 2005. Available from: <http://www.surveyofindia.gov.in/files/nmp/National\%20 Map\%20Policy.pdf>. [12 March 2017].

Govt. of India 2012, NDSAP-2012. Available from: <https://data. gov.in/sites/default/files/NDSAP.pdf>. [26 October 2017].

Habib, I 1974, 'Cartography in Mughal India', Proceedings of the Indian History Congress, vol. 35, pp.150-162.

Heaney, GF 1952, 'The survey of India since the Second World War', The Geographical Journal, vol. 118, no. 3, pp. 280-293.

Heaney, GF 1967, 'Sir George Everest', The Geographical Journal, vol. 133, no. 2, pp. 209-211.

Keay, J 2001, The Great Arc, the dramatic tale of how India was mapped and Everest was named, Harper Collins Publishers, London.

Mackay, EJH 1938, Further excavations at Mahaenjo-Daro: Being an official account of archaeological excavations at Mahenjo-daro carried out by the Government of India between the years 1927 and 1931, vol.1, Government of India Press, New Delhi.

Markham, CR 1878, A memoir on the Indian surveys, Allen \& Co., London. 
Mishra, S, Singh, S, Singh, P \&Trikamji, B 2015, 'Trigonometrical survey of India and Namingof Peak XV as Mt. Everest', Indian Journal of History of Science, vol. 50, no.4, pp. 642-645.

Phillimore, RH 1945, Historical Records of the Survey of India, 18th Century, vol. I, Survey of India, Dehra Dun.

Phillimore, RH 1950. Historical Records of the Survey of India (1800-1815), vol. II, Survey of India, Dehra Dun.

Phillimore, RH 1954, Historical Records of the Survey of India (1815 to 1830), vol. III, Survey of India, Dehra Dun.

Phillimore, RH 1958, Historical Records of the Survey of India (1830 to 1843) George Everest, vol. IV, Survey of India, Dehra Dun.

Phillimore, RH 1968, Historical Records of the Survey of India, Andrew Waugh (1844-1861), vol. V, Survey of India, Dehra Dun.

Roy, RD 1986, 'The Great Trigonometrical Survey of India in a historical perspective', Indian Journal of History of Science, vol.21, no.1, pp. 22-32.

Seidenberg, A 1978, 'The origin of Mathematics', Archive for History of Exact Sciences, vol.18, no.4, pp.301-342.

Srivastava, GS 2014, An introduction to Geoinformatics, McGraw Hill Education (India) Pvt. Ltd. New Delhi.

Staal, F 1999, 'Greek and Vedic Geometry', Journal of Indian Philosophy, vol. 27, no.1-2, pp.105-127.

Strahan, C 1902, 'The Survey of India' in Professional Papers of the Corps of Royal Engineers, eds AT Moore, Royal Engineers Institute, Occasional Papers, vol. XXVIII, pp. 141-171.

Survey of India, Annual Report, 2016-2017. Available from: <http://www.surveyofindia.gov.in/files/Annual\%20 Report\%20SOI2017.pdf>. [18 April 2018].

van der Waerden, BL 1983, Geometry and algebra in ancient civilizations, Springer-Verlag, Heidelberg. 